\title{
Diagnostic Potential of Some Neurological Markers in Organophosphate Insecticide Poisoning
}

\author{
Hosam A. M. Elshebiny ${ }^{1}$, Amina M. Medhat ${ }^{2 *}$, Ahmed O. Mostafa ${ }^{2}$, Aya S. Khater ${ }^{3}$ and Mohamed \\ A. Abdel-Aziz ${ }^{1}$ \\ ${ }^{1}$ Poison Control Center, Ain Shams University Hospitals, Cairo, Egypt; ${ }^{2}$ Department of Biochemistry, Faculty of \\ Science, Ain Shams University, Abbassia 11566, Cairo, Egypt, ${ }^{3}$ Department of Forensic Medicine \& Clinical Toxicology, \\ Faculty of Medicine, Ain Shams University.
}

\section{ARTICLE INFO}

Article history:

Received 26 January 2016

Accepted 24 February 2016

Keywords:

Organophosphate;

S100B protein;

Neuron specific enolase

Myelin basic protein;

Acetylcholine;

Pseudocholinesterase.

\begin{abstract}
A B S T R A C T
Organophosphates (OPs) are lipophilic compounds; they penetrate the blood brain barrier, resulting in severe brain damage. The toxic effects of organophosphate poisoning (OPP) on the central nervous system (CNS) include nonspecific symptoms as irritability, restlessness, disorientation and confusion. The objective of this study was to evaluate early levels of serum S100B protein, neuron specific enolase (NSE) and myelin basic protein (MBP) to assess their potential as diagnostic and/or prognostic tools that may aid in the management of organophosphates-poisoned patients and chronically exposed subjects. This study was conducted on 40 adult patients of both sexes who were admitted with acute OPP to the Poison Control Center, Ain Shams University Hospitals (PCCASUH). In addition, twenty chronically exposed subjects and 30 healthy volunteers were also included in this study and served as chronic exposure group and control group, respectively. Our data revealed that there were significant differences between the level of markers of nerve cells degeneration $\{$ S100B, NSE, MBP, acetylcholine (ACh) and pseudocholinesterase (PChE) \} in patient groups when compared to the control group. Furthermore, the employed markers have also exhibited an alarming increase for OPs chronic exposure, which may indicate an acceleration of neuro-degenerative effects due to such exposure. Therefore, it can be suggested that serum markers such as S100B, NSE and MBP can be used as early diagnostic markers for detection of brain cells degeneration in chronic exposure to OPs.
\end{abstract}

\section{Introduction}

Organophosphate compounds are a diverse group of chemicals which are used as pesticides. Organophosphate poisoning is a major problem all over the world, particularly in the developing countries. World Health Organization estimates that one million serious unintentional poisonings occur every year and an additional two million people are hospitalized for suicide attempts with pesticides ${ }^{[1]}$.

Organophosphate-induced brain damage is defined as progressive damage to the brain, resulting from the cholinergic neuronal excitotoxicity and dysfunction induced by OP-induced irreversible acetylcholinesterase (AChE) inhibition. This delayed secondary neuronal damage that occurs mainly in the cholinergic regions of the brain that contain dense accumulations of cholinergic

\footnotetext{
* Corresponding author.

E-mail address: aminamedhat@yahoo.com
}

neurons and the majority of cholinergic projection, might be largely responsible for persistent profound neuropsychiatric and neurological impairments (memory, cognitive, mental, emotional, motor and sensory deficits) in the victims of OPP ${ }^{[2]}$.

On the other hand, long-term exposure to low levels of organophosphate pesticides may produce neuropsychiatric symptoms ${ }^{[3]}$. The majority of welldesigned studies found a significant association between long-term, low-level exposure to pesticides containing organophosphates and impaired neurobehavioral function, which is consistent, small to moderate in magnitude and concerned primarily with neurobehavioral functions such as working memory/attention, psychomotor speed, executive function and visuospatial ability ${ }^{[4]}$.

Neurochemical and immunohistological studies have demonstrated the feasibility of using some protein markers 
for evaluating the pathological changes in the nervous system. These are specific isoenzymes or isoproteins such as S100B protein, NSE and MBP specifically distributed in glial cells, neurons and myelin sheath, respectively ${ }^{[5,6]}$.

In the current study serum S100B, NSE and MBP were used to determine their potential as early markers for brain cells degeneration in acute and chronic OPs exposure.

\section{Subjects and Methods}

This study was conducted on 40 adult patients of both sexes who were admitted with acute OPP to the PCCASUH. In addition, 20 chronically exposed subjects and 30 healthy volunteers were also included. The subjects included in the study were divided into the following groups:

Group (I): Control group: consisted of 15 males and 15 females (normal healthy volunteers who were not exposed to OPs).

Group (II): Chronic OPs exposure group: This group consisted of 15 males and 5 females, who were selected from farmworkers chronically exposed to OPs during their work in the fields and did not show any cholinergic symptoms.

\section{Group (III): Acute OPP patients group subdivided into:}

Group (IIIa): Acute moderate OPP patients group: This group consisted of 3 males and 17 females, who were admitted with mild, transient and spontaneously resolving symptoms (lacrimation, salivation, miosis and fasciculation).

Group (IIIb): Acute severe OPP patients group: This group consisted of 7 males and 13 females who were admitted with severe or life threatening symptoms (incontinence, apneic spells, acute respiratory distress syndrome, diminished reflexes, seizures and coma).

Blood samples were collected from all subjects to determine serum levels of neurological markers S100B, NSE [7] and MBP [8] using ELISA-based assays (DiaMetra, USA), PChE using kinetic colorimetric assay [9] (Biochemical enterprise, Italy), ACh using colorimetric assay technique according to the method of Steinhart ${ }^{[10]}$, as well as markers for cardiac muscle functions \{lactate dehydrogenase (LDH) ${ }^{[11]}$, and creatine phosphokinase (CPK) $\left.{ }^{[12]}\right\}$, using kinetic colorimetric assays (Spectrum, Egypt). Sodium and potassium were measured using Easylyte $\mathrm{Na} / \mathrm{K}$ ion selective electrodes analyzer, (Medica Corp, USA) following the manufacturers' instructions.

In the present study, all data were statistically analyzed by SPSS software version (21.0). Results were expressed as mean \pm standard error of the mean (SEM). Statistical analysis was performed using non-parametric analysis (Mann-Whitny and Kruskal-Wallis Test). Significant values were $\mathrm{P}<0.05$ and highly significant at $\mathrm{P}<0.01$.

\section{Results}

The data presented in this study showed that there were significant differences between the levels of neurological markers (S100B, NSE, MBP, ACh and PChE) in the patient groups exposed to OPs, either chronically or acutely and the control group. Serum S100B, NSE, MBP and $\mathrm{ACh}$ exhibited a significant increase in patient groups as compared to the control group. On the other hand, PChE showed a significant decrease in these groups when compared to the control group.

Furthermore, markers for systemic functions also showed significant changes among patient groups when compared to control group, where $\mathrm{LDH}$ and CPK exhibited significant increase in OPs exposed individuals as compared to control group indicating the occurrence of marked tissue damage.

Serum sodium showed no significant difference in patients groups when compared with the control group. On the other hand serum potassium showed a statistically high significant decrease with the increase in severity of OPP patients in all patient groups when compared with the control group.

Mean and SEM for all studied parameters in different groups are summarized in Table (1), which clearly demonstrates also that all markers are significantly different from one another except potassium levels in groups (IIIa and IIIb) and CPK level in group (IIIb).

Spearman correlations between the changes percent (from control) in the studied parameters in all patients showed a strong positive correlation $(\mathrm{P}<0.001)$ between S100B, NSE, MBP, ACh, LDH and CPK. These parameters were negatively correlated with $\mathrm{PChE}(\mathrm{P}<$ 0.001) (data not shown).

\section{Discussion:}

The public health importance of OPP is reflected in the huge number of deaths due to suicidal and accidental toxicity from these compounds. History of exposure, characteristic signs and symptoms of toxicity and low serum cholinesterase levels make the diagnosis almost certain ${ }^{[13]}$.

Organophosphorus pesticides inhibit esterase enzymes, especially acetylcholinesterase in synapses and on redcell membranes and butyrylcholinesterase in plasma. Acetylcholinesterase inhibition results in accumulation of acetylcholine and overstimulation of acetylcholine receptors in synapses of the autonomic nervous system, CNS, and neuromuscular junctions ${ }^{[14]}$.

In the present study there was a marked significant decrease in active serum PChE levels in all patient groups when compared with the control group. Also there were highly significant decreases between group (II) and groups (IIIa, IIIb), while there was a significant decrease between group (IIIa) and group (IIIb) which may be due to the depletion of active serum PChE. These results are in agreement with Hassan and Madboly ${ }^{[15]}$, who found a significant decrease in PChE which correlated with the increase in severity score of the OPs exposed patients. 
Table 1: Differences in the studied parameters among all groups.

\begin{tabular}{|c|c|c|c|c|c|}
\hline \multicolumn{2}{|l|}{ Parameters } & Control group (I) & Group (II) & Group (IIIa) & Group (IIIb) \\
\hline \multicolumn{2}{|c|}{$\begin{array}{l}\text { Sex Males/females } \\
(\text { Males\%) }\end{array}$} & $15 / 15(50 \%)$ & $15 / 5(75 \%)$ & $3 / 17(15 \%)$ & $7 / 13(35 \%)$ \\
\hline $\begin{array}{l}\text { S100B } \\
(\mathrm{pg} / \mathrm{ml})\end{array}$ & $\begin{array}{l}\text { Mean } \pm \text { SEM } \\
\mathrm{P} \text { value } \\
\mathrm{P}^{*} \text { value } \\
\mathrm{P}^{* *} \text { value }\end{array}$ & $61.0 \pm 2.1$ & $\begin{array}{c}107.4 \pm 4.6 \\
0.001\end{array}$ & $\begin{array}{c}194.7 \pm 10.1 \\
0.001 \\
0.001\end{array}$ & $\begin{array}{c}434.4 \pm 15.8 \\
0.001 \\
0.001 \\
0.001\end{array}$ \\
\hline $\begin{array}{c}\text { NSE } \\
(\mathrm{ng} / \mathrm{ml})\end{array}$ & $\begin{array}{l}\text { Mean } \pm \mathrm{SEM} \\
\mathrm{P} \text { value } \\
\mathrm{P}^{*} \text { value } \\
\mathrm{P}^{* *} \text { value }\end{array}$ & $9.1 \pm 0.4$ & $\begin{array}{c}16.7 \pm 0.8 \\
0.001\end{array}$ & $\begin{array}{c}21.36 \pm 1.0 \\
0.001 \\
0.002\end{array}$ & $\begin{array}{c}40.6 \pm 2.2 \\
0.001 \\
0.001 \\
0.001\end{array}$ \\
\hline $\begin{array}{c}\text { MBP } \\
(\mathbf{u g} / \mathrm{L})\end{array}$ & $\begin{array}{l}\text { Mean } \pm \mathrm{SEM} \\
\mathrm{P} \text { value } \\
\mathrm{P}^{*} \text { value } \\
\mathrm{P}^{* *} \text { value }\end{array}$ & $3.01 \pm 0.12$ & $\begin{array}{c}3.64 \pm 0.1 \\
0.001\end{array}$ & $\begin{array}{c}4.06 \pm 0.19 \\
0.001 \\
0.039\end{array}$ & $\begin{array}{c}5.03 \pm 0.25 \\
0.001 \\
0.001 \\
0.003\end{array}$ \\
\hline $\begin{array}{l}\text { PChE } \\
\text { (U/L) }\end{array}$ & $\begin{array}{l}\text { Mean } \pm \mathrm{SEM} \\
\mathrm{P} \text { value } \\
\mathrm{P}^{*} \text { value } \\
\mathrm{P}^{* *} \text { value }\end{array}$ & $7474 \pm 278$ & $\begin{array}{c}4531.5 \pm 229.2 \\
0.001\end{array}$ & $\begin{array}{c}1326.1 \pm 62.5 \\
0.001 \\
0.001\end{array}$ & $\begin{array}{c}1102.7 \pm 52.5 \\
0.001 \\
0.001 \\
0.012\end{array}$ \\
\hline $\begin{array}{c}\mathrm{ACh} \\
(\mathrm{ug} / \mathrm{dl})\end{array}$ & $\begin{array}{l}\text { Mean } \pm \mathrm{SEM} \\
\mathrm{P} \text { value } \\
\mathrm{P}^{*} \text { value } \\
\mathrm{P}^{* *} \text { value }\end{array}$ & $7.17 \pm 0.12$ & $\begin{array}{c}8.22 \pm 0.32 \\
0.01\end{array}$ & $\begin{array}{c}9.51 \pm 0.25 \\
0.001 \\
0.012\end{array}$ & $\begin{array}{c}16.79 \pm 0.92 \\
0.001 \\
0.001 \\
0.001\end{array}$ \\
\hline $\begin{array}{l}\text { LDH } \\
(\mathbf{U} / \mathbf{L})\end{array}$ & $\begin{array}{l}\text { Mean } \pm \text { SEM } \\
\mathrm{P} \text { value } \\
\mathrm{P}^{*} \text { value } \\
\mathrm{P}^{* *} \text { value }\end{array}$ & $290.3 \pm 8.7$ & $\begin{array}{c}356.4 \pm 8.2 \\
0.001\end{array}$ & $\begin{array}{c}425.2 \pm 19.5 \\
0.001 \\
0.006\end{array}$ & $\begin{array}{c}758.3 \pm 32.3 \\
0.001 \\
0.001 \\
0.001\end{array}$ \\
\hline $\begin{array}{l}\text { CPK } \\
(\mathbf{U} / \mathbf{L})\end{array}$ & $\begin{array}{l}\text { Mean } \pm \text { SEM } \\
\mathrm{P} \text { value } \\
\mathrm{P}^{*} \text { value } \\
\mathrm{P}^{* *} \text { value }\end{array}$ & $122.2 \pm 5.2$ & $\begin{array}{c}152.1 \pm 7.2 \\
0.002\end{array}$ & $\begin{array}{c}198.4 \pm 8.6 \\
0.001 \\
0.001\end{array}$ & $\begin{array}{c}206.4 \pm 8.3 \\
0.001 \\
0.001 \\
\text { N.S. }\end{array}$ \\
\hline $\begin{array}{c}\mathrm{Na}^{+} \\
(\mathbf{m E q} / \mathbf{L})\end{array}$ & $\begin{array}{l}\text { Mean } \pm \text { SEM } \\
\mathrm{P} \text { value } \\
\mathrm{P}^{*} \text { value } \\
\mathrm{P}^{* *} \text { value }\end{array}$ & $138.0 \pm 0.4$ & $\begin{array}{l}138.4 \pm 1.1 \\
\text { N.S. }\end{array}$ & $\begin{array}{c}136 \pm 0.5 \\
\text { N.S. } \\
\text { N.S. }\end{array}$ & $\begin{array}{l}135.3 \pm 1.4 \\
\text { N.S. } \\
\text { N.S. } \\
\text { N.S. }\end{array}$ \\
\hline $\begin{array}{c}\mathbf{K}^{+} \\
(\mathbf{m E q} / \mathbf{L})\end{array}$ & $\begin{array}{l}\text { Mean } \pm \text { SEM } \\
\mathrm{P} \text { value } \\
\mathrm{P}^{*} \text { value } \\
\mathrm{P}^{* *} \text { value }\end{array}$ & $3.76 \pm 0.04$ & $\begin{array}{c}3.48 \pm 0.07 \\
0.003\end{array}$ & $\begin{array}{c}3.31 \pm 0.07 \\
0.001 \\
\text { N.S. }\end{array}$ & $\begin{array}{c}3.42 \pm 0.16 \\
0.001 \\
\text { N.S. } \\
\text { N.S. }\end{array}$ \\
\hline
\end{tabular}

Data are represented as mean \pm SEM.

Group $(I)=$ Control group, Group $(I I)=$ Chronic OPs exposure group, Group $($ IIIa $)=$ Acute moderate OPP group, Group $($ IIIb $)$

$=$ Acute severe OPP group. N.S. = Non-significant, $P<0.05=$ Significant, $P<0.01=$ Highly significant,

$P$ value =versus control group, $P *$ value $=$ versus group $(I I), P * *$ value $=$ versus group $($ IIIa $)$.

$\phi=$ No significant differences were found between males and females. 
Our data showed that serum levels of ACh were highly significantly increased in all patient groups when compared with the control group. These results were in accordance with Nirogi et al., ${ }^{[16]}$ who stated that, functional changes in extracellular ACh levels are evident only in the presence of cholinesterase inhibition. In addition, Sarter and Bruno ${ }^{[17]}$ reported that chronic exposure to insecticides in farmworkers causes psychosis which could be caused by hypercholinergic activity due to accumulation of ACh.

These data may be explained by the fact that OP compounds can inhibit $\mathrm{AChE}$, and resulting in over consumption of $\mathrm{AChE}$ isoenzymes in serum, RBCs and neuron synapsis of CNS, and consequently the accumulation of $\mathrm{ACh}$, which evokes the muscarinic and nicotinic receptors causing increase in free radicals generation and increase in the oxidative stress. This process exhausted the nerve cells and may lead to degenerative effect to the nerves or increase in the cell membrane permeability leading to the damage of blood brain barrier ${ }^{[18,19]}$.

Leakage of S100B, NSE and MBP from nerve cells to the interstitial fluid then to blood may be helpful in detection of the extent of damage of the CNS, also they may reflect the degree of clinical severity and prediction of mortality in acute OPP ${ }^{[5,20,21]}$.

The results of the current study showed that, S100B protein was highly significantly increased in all patient groups compared to control group. These results are in good agreement with the study of Bozkurt et al., ${ }^{[5]}$ who found that serum S100B level was acutely increased 2 hours after chlorpyrifos administration and remained high for 12 hours.

Neuron-specific enolase in the present study revealed a significant increase in its activity in all patient groups compared to the control group, showing maximum elevation in group (IIIb) followed by Group (IIIa) then group (II). These results are in good agreement with Bozkurt et al., ${ }^{[5]}$ who found that serum NSE level was markedly increased 2 hours after chlorpyrifos administration and remained high for 12 hours. In addition, El-Maraghi et al. ${ }^{[22]}$ reported that NSE can be used as a potentially useful marker for brain damage and can be considered to be a relevant parameter for assessing the prognosis of brain injury.

In the present study MBP was elevated in all patient groups when compared with the control group. Our results are consistent with the study of Hernández et al., [23] who suggested a neurotoxic damage of trichlorfon on neuronal and astrocyte functional balance and abnormal myelin formation consequent to the cell damage.

Mondello et al. ${ }^{[20]}$ stated that, S100B and NSE are cytoplasmic components while MBP is a myelin sheath component. In the present study we noticed that, there were marked increases in S100B and NSE when compared to the increase of MBP in OPP patients. This may be explained by the low effect of OPs on the myelin sheath which may be due to the increase in free radical generation and lipidperoxidation of myelin sheath, leading MBP to leak out to blood stream. However, in early stages of OP toxicity, the effects may not be prominent on myelin sheath ${ }^{[24]}$.

The presence of muscle fiber necrosis in OPP has been already demonstrated in many animal experimental studies ${ }^{[25]}$. Three types of muscle injuries (paralysis) are noticed in OPP. Type $I$ is due to continued depolarization at neuro-muscular junction, type II due to intermediate syndrome and type III due to delayed polyneuropathy ${ }^{[26]}$.

There have been many human studies showing elevations in serum CPK and serum LDH levels following acute OPP as a result of muscle injury. There is also biopsy proven evidence of muscle fiber necrosis in humans ${ }^{[27]}$.

In the present study there were highly statically significant increases in serum LDH and CPK in all patient groups when compared with the control group, however the increase of CPK in group (II) was within the normal range (normal range of the kit $22-198 \mathrm{U} / \mathrm{L}$ ). These results are in good agreement with Sen et al., who reported that serum LDH and CPK activity significantly increased with the increase in the severity grade of OPP when compared with the control group. They explained this data by the presence of muscle fiber necrosis in OPP causing serum LDH elevation which is proportional to the severity of poisoning. Also rhabdolmyolysis may be continued in intermediate syndrome causing continuous increase in serum LDH and $\mathrm{CPK}^{[19]}$.

Our data showed no significant difference in serum sodium levels in all patient groups when compared to the control group. This was in accordance with Malla et al.o, ${ }^{[28]}$ who stated that the investigations at admission of OPP patients showed normal serum levels of sodium.

On the other hand, serum potassium showed a significant decrease in all patient groups when compared to control group. In Turkey, Sahin et al. ${ }^{[29]}$ found a decrease in serum potassium levels. Hypokalemia could be attributed to sympathetic over activity in OPP or as a result of pancreatitis. Also severe vomiting and diarrhea that can be due to muscarinic manifestations can lead to hypokalemia ${ }^{[30]}$.

In conclusion, serum S100B, NSE and MBP can be used as early markers in brain cells degeneration in OPP. Serum S100B and NSE were found to be good laboratory markers for diagnosing and predicting the degree of severity of OPP in acute poisoning patients. Chronic exposure to OPs affected the CNS cells where neuro-degenerative markers (S100B and NSE) showed significant increase in chronic group. There is minimal effect of OPs on myelin sheath of the nervous cell, as serum MBP showed mild increase when compared to serum S100B and NSE. 


\section{References}

1) Banerjee, I., Tripathi, S. K. and Roy, A. S. (2012). Clinico-epidemiological characteristics of patients presenting with organophosphorus poisoning. North Am J Med Sci; 4(3):147-150.

2) Chen, Y. (2012). Organophosphate-induced brain damage: mechanisms, neuropsychiatric and neurological consequences, and potential therapeutic strategies. Neurotoxicol; 33(3):391-400.

3) Salvi, R. M., Lara, D. R., Ghisolfi, E. S., Portela, L. V, Dias, R. D. and Souza, D. O. (2003). Neuropsychiatric evaluation in subjects chronically exposed to organophosphate pesticides. Toxicol Sci; 72:267-271.

4) Ross, S. M., McManus, I. C., Harrison, V. and Mason, O. (2013). Neurobehavioral problems following low-level exposure to organophosphate pesticides: a systematic and meta-analytic review. Crit Rev Toxicol; 43(1):21-44.

5) Bozkurt, A., Yardan, T., Ciftcioglu, E., Baydin, A., Hakligor, A., Medine, B. M. and Sirri, B. S. (2010). Time course of serum S100B protein and neuron-specific enolase levels of a single dose of chlorpyrifos in rat. Basic Clini Pharmacol Toxicol; 107:893-898.

6) Ou-Yang, M. and Van-Nostrand, W. E. (2013). The absence of myelin basic protein promotes neuroinflammation and reduces amyloid $\beta$-protein accumulation in Tg-5xFAD mice. J Neuroinflam; 10: $134-146$.

7) Sawauchi, S., Taya, K., Murakami, S., Ishi, T., Ohtsuka, T., Kato, N., Kaku, S., Tanaka, T., Morooka, S., Yuhki, K., Urashima, M. and Abe, T. (2005). Serum S-100B protein and neuron-specific enolase after traumatic brain injury. No Shinkei Geka; 33(11):1073-1080.

8) Kricka, L. (2000). Interferences in immunoassays still a threat. Clin Chem; 46:1037-1038.

9) Young, D. S. (2000). Effect of drugs on clinical laboratory Tests, $5^{\text {th }}$ ed. AACC press, Washington.

10) Steinhart, J. R. (1968). Colorimetric assay of acetylcholine by gallocyanine. Biochimica et Biophysica Acta; 158(1):171-173.

11) Van der heiden, C., Ais, B., Ardt, G. and Rosallsis, W. (1994). Approved recommendation on IFCC methods for the measurement of catalytic concentration of enzymes. Part 8. IFCC method for LDH. EnrJ Clinical Chemclin Biochem; 32: 639655.

12) Tietz, N. W. (2008). Enzymes. In "Fundamentals of clinical chemistry" Pantenghini M. and Bais R. eds. $6^{\text {th }}$ edition; Saundars, USA. 317-336.

13) Basheer, A., Mookkappan, S., Shanmugham, V., Natarajan, N. and Kulirankal, K. (2014). Black coloured urine following organophosphorus poisoning: Report of two cases. Case Reports in Critical Care, Article ID 706021: 1 - 3.

14) Eddleston, M., Buckley, N. A., Eyer, P. and Dawson, A. H. (2008). Management of acute organo- phosphorus pesticide poisoning. Lancet; 371: 597607.

15) Hassan, N. A. M. and Madboly, A. G. (2013). Correlation between serum creatine phosphokinase and severity of acute organophosphorus poisoning: A prospective clinical study. J Environ Sci Toxicol Food Technol; 4(5): 18-29.

16) Nirogi, R., Mudigonda, K., Kandikere, V. and Ponnamaneni, R. (2009). Quantification of acetylcholine, an essential neurotransmitter, in brain microdialysis samples by liquid chromatography mass spectrometry. Biomed Chromatogr; 24: 39-48.

17) Sarter, M. and Bruno, J. P. (1998). Cortical acetylcholine, reality distortion, schizophrenia, and lewy body dementia: Too much or too little cortical acetylcholine. Brain Cogn; 38: 297-316.

18) Abou Donia, M. B. (2003). Organophosphorus ester induced chronic neurotoxicity. Arch Env Health; 58(8): 484-497.

19) Sen, R., Nayak, J. and Khadanga, S. (2014). Study of serum cholinesterase, CPK and LDH as prognostic biomarkers in organophosphorus poisoning. Int $J$ Med Res Rev; 2(3):185 - 189.

20) Mondello, S., Jeromin, A., Streeter, J., Hayes, R. and Wang, K. (2011). Blood-based diagnostics of traumatic brain injury. Mol. Diagn., 11(1): 65-78.

21) Yardan, T., Baydin, A., Acar, E., Ulger, F., Aygun, D., Duzgun, A. and Nar, R. (2013). The role of serum cholinesterase activity and S100B protein in the evaluation of organophosphate poisoning. Hum Exp Toxicol.; 32(10):1081-1088.

22) El-Maraghi, S., Yehia, H., Hossam, H., Yehia, A. and Mowafy, H. (2013). The prognostic value of neuron specific enolase in head injury. Egy J Crit Care Med; 1: 25-32.

23) Hernández, Y. T., Barragán, I. R. and Rubio, A. C. (2013). Neurotoxic potential of trichlorfon to multiple sublethal doses in wistar rats. Acta biol. Colomb; 18(3): 479-488.

24) Nurulain, S. M., Szegi, P., Tekes, K. and Naqvi, S. N. (2013). Antioxidants in organophosphorus compounds poisoning. Arh Hig Rada Toksikol; 64: 169-77.

25) Bhattacharyya, K., Phaujdar, S., Sarkar, R. and Mullick, O. S. (2011). Serum creatine phosphokinase: A probable marker of severity in organophosphorus poisoning. Toxicol Int.; 18(2): 117-123.

26) Yang, C. and Deng, J. (2007). Intermediate syndrome following organophosphate insecticide poisoning. J Chin Med Assoc, 70(11): 467-472.

27) John, M., Oommen, A. and Zachariah, A. (2003). Muscle injury in organophosphorous poisoning and its role in the development of intermediate syndrome. Neurotoxicol; 24(1): 43-53.

28) Malla, G., Basnet, B., Vohra, R., Lohani, S. P., Yadav, A. and Dhungana, V. (2013). Parenteral organophosphorus poisoning in a rural emergency department: a case report. BMC Research Notes; 6:524-528. 
29) Sahin, I. C., Onbasi, K., Sahin, H., Karakaya, C., Ustun, Y. and Noyan, T. (2002). The prevalence of pancreatitis in organophosphate poisonings. Hum Exp Toxicol; 21(4):175 -177.
30) Salameh, S., Weiss, T. and Amitai, Y. (2008). Fungicide (Rubigan) overdose mimicking organophosphate poisoning. IMAJ; 10:804-805. 